\title{
分野別研究動向（社会運動）
}

一一失われた敵対性と「さまよう主体」のゆくえ——

\section{稲葉 奈々子*}

\section{1 現代社会論としての社会運動論}

1990 年代末以降の反グローバリズム運動, 2000 年代の民主化運動やオキュパイ 運動など, 過去 20 年で世界的に社会運動が活性化し, 研究も多く現れた. 日本で は, これらの運動がそれほど活況を呈さなかったこともあり，著書として刊行され た社会運動研究は, もっぱら住民運動, なかでも環境運動が多い（長谷川編 2001; 西城戸 2008; 帯谷 2004; 中澤 2005). また, NPO や社会的企業, あるいはボラン ティア活動も含めた「抗議型」ではない社会運動を射程に入れた研究が増加した (本郷 2007; 安立 2008; 仁平 2011).このように, 「社会運動」とされる現象の外 延が広がってきたことが，この間の日本の特徴といえる.「抗議型」ではない運動 の場合も, 行政との協働や市民参加にとどまらず, 制度变革や権力関係の変化に結 びつくオルタナティブな構想や政策を提言することに, NPOの「運動性」を見出 そうとしている（西城戸 2008; 安立 2008).

社会運動論は，現代の社会変動とそれに伴う社会矛盾を明らかにし，社会がとり うる方向性を見定める材料を提供することで, すぐれた現代社会論としても読まれ てきた，日本にも大きな影響を及ほした「新しい社会運動論」は，生活世界への国 家の介入や産業主義への対抗という, 労働運動とは異なる争点を提示するものとし て読まれ, 現在の社会問題にも波及力をもっている. それ以降の社会運動研究では, 新しい社会問題を「発見」し, 現代社会論的な論点を提供する方向がやや不振だっ た一方で, 大きく次のような 2 つ流行が生み出された. それが, 社会運動の制度 化に即した政策科学化を指向する研究と, 行為者のアイデンティティに注目する研 究である.

昨今の日本をみると, 2008 年の反貧困運動, 2011 年の東日本大震災以降の反原 発運動, 2015 年の安保法制反対運動など, 社会運動がかつてなく活性化している ようにみえる。半世紀近くの歳月を経て, 路上での大規模な直接行動に人々が再び 繰り出すようになったのはなぜか. 社会運動論は, この問いにどのように答えるこ とができるのだろうか.このような問題関心から本稿を論じるため, 以下では, 主

* 上智大学総合グローバル学部教授 hqm10620@nifty.ne.jp 
に経験的な社会運動研究について論じていく ${ }^{1)}$. 時期的には冷戦終結を起点とし, 「9.11」の影響を受けた社会運動が活性化した 2000 年以降を含め, 幅を広くとって

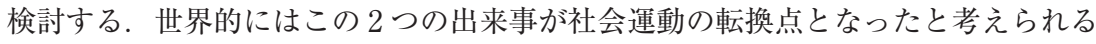
ためである.

\section{2 政策科学を志向する社会運動研究}

日本の社会運動研究は, 住民運動を主要なテーマとし, とくに環境運動を多くと りあげている，そうした傾向は 2000 年代以降も確認できる，そのなかで，政策的 な課題となって現代社会の「常識」としてビルトインされた価值観を扱う社会運動 研究が登場した，長谷川編（2001）は，社会学さらには社会運動論の目指す方向性 の 1 つとして，政策志向的たることをあげている．このことは，第 1 に旧来型の対 立的な社会運動が少なくなったこと，第 2 に対立よりはむしろ NGO P NPO など 行政や企業と協同する現象を把握しょうとする志向による。こうした見方では，社 会の構想を市民が積極的な参加によって担うという意味で, 社会運動と NGO ・ NPO の目指すところが大きく異なるわけではない（安立 2008）.

しかし政策科学的アプローチは，問題を開示するという「歴史的役割」をすでに 果たした社会運動を対象にした研究が多い. 長谷川（長谷川編 2001; 長谷川 2003）, 西城戸 (2008), 带谷（2004）, 中澤（2005）は, 環境運動を扱っているが, その解 釈は，近代合理主義的な価值観への異議申し立てであり，中央集権的なテクノクラ 一トに対する民主化運動であるとする「新しい社会運動論」の域を出ない．さらに は 1960 年代に提示された社会問題の多くが, 公的に問題として認知され, 問題解 決の回路が制度化されていった，社会運動論もまた，制度化に即した政策科学化の 道をたどり，環境研究はまちづくりや地域再生と連結するような志向をもつように なっていった．住民が主体的に行政と協働してまちづくりが進められるイメージで ある.

つまり，まちづくりや地域再生への住民参加は，抗議型の社会運動の時代のよう に行政が住民による紏弾や異議申し立ての対象ではなく，協働の相手となったこと を意味する. 結果として, 両者の間に対立や亀裂を想定しない方向に研究は展開し ていった，それに対して，地方自治において既成の政治的回路が機能しないがゆえ に，住民運動の形式をとって社会運動が現れたと解釈する研究も登場してきた．住 民投票が提起した民主主義の問題は，既存の政党では複雑化した市民社会の利益を 代表しきれないことを示しているという考え方である．したがって次節で扱うよう に, これらの研究に扔いては, 社会運動は民主主義の問題としてとらえられる2).

今日活性化している社会運動は, 反原子力運動や反戦平和運動, 反差別運動とい った,「古典的な」争点を揭げる社会運動である.これらの争点については, 問題 解決の回路がいまだ制度化されていないということになる，そうであるがゆえに， 国会議事堂前でのデモが活性化し，「民主主義って何だ」「「民主主義ってこれだ」 
(SEALDs 2015; 高橋・SEALDs 2015）という問いがリアリティをもって受け止め られるのだろう。

次節で考察するように，投票では実現できない民主主義の問題に答えを見出そう とする研究は，その答えは議会の外の市民社会にあると考えている.

\section{3 マジョリティにとっての参加と民主主義の問題一一敵対性の喪失}

社会運動にとって民主主義は永遠のテーマだともいえる. 1960 年代にすでに参 加はマイノリティにとっての民主主義の問題として掲げられてきた. 今あらためて 住民運動の担い手たるマジョリティも,「誰が」決めるのか, という問題を争点と するようになった.

中澤（2005）はそのプロセスを「根源的民主主義」として分析する．環境運動は， 被害者としての住民の補償問題から公共性を問題にする運動へとフレームを転換さ せていった．住民の参加を排除した閉鎖的で中央集権的な決定への異議申し立てと しての社会運動であり，それがローカルに根ざした運動に向かうというものである. 原発建設に反対する巻町の住民投票もまた，政治的意志決定が「官」に独占されて きたことに異議を申し立て, 市民が意志決定を取り戻したという「公共」にかかわ る事項の決定を誰がコントロールするかという問題として位置づけられる.

また，単に住民が公共にかかわる事項の決定のイニシアチブを取り戻したという だけではなく，「戦後の『公共性』」の転換点を示している（中澤 2005：28）とす る.「公共性」の転換とは, 「開発型の政治から, 新しい価值観を求める政治への模 索」である．開発主義の「お金」という利益誘導の政治に異議を申し立てる運動の 理想の帰結として提示されるのが,「内発的発展」である (中澤 2005：42). しか し，原発建設は白紙撤回できたが，「根源的民主主義によって目覚めた町民たちが, こんどは『原発』という外来的発展と決別して, 内発的発展の道を進み始めるとい う期待が生まれた」のにもかかわらず, 結果として新潟市と合併して地域開発は大 きな自治体にすがってしまった（中澤 2005：265）ことをもって, 主体的な地域開 発につながらず，「内発的発展」が不発に終わった（中澤 2005：250）と評価する ${ }^{3}$.

帯谷（2004）もまた, 市民グループがもつ「領域（分野）横断的で地域性を有し たローカルな知のまとまり」を「もう１つの専門性」として政策決定に不可欠なも のとする (帯谷 2004: 291). テクノクラートと市民の対立というステージから, 市民セクターと行政の協働というセカンド・ステージに移行した（帯谷 2004: 297）という解釈である。「住民の生活」という論点を環境運動が欠いてきたと指摘 し, 地域住民の意思決定や彼らのアイデンティティ, 住民生活や地域再生活動を支 援するための政策や制度など，ローカルの視点が置き去りになっているという（帯 谷 2004: 299). 中澤も「対立から参加へ, 主体化へという道筋を」どのように描 いていけるのか, という疑問を最後に提示している（中澤 2005: 257-8）.

いずれも, 住民が, 反開発主義的な価值観にもとづいて内発的発展を主体的に担 
っていくことが期待されている. しかし住民投票という手段が選ばれたことと，内 発的発展を主体的に志向することは必然的に結びつくものではない. 住民投票は, 議会で代表されない市民社会を政治的意思決定に反映させる役割を果たす。しかし 直接民主主義を求める市民社会と代表制にもとづく議会を隔てる線は, 争点となる 価值観の線に沿って引かれているわけではない. 決定において直接民主主義を要求 する個人が, 反開発主義的な価值観をもっているとしたら, その両者の関係を理解 する補助線が必要である.

それに対して久保田ほか編（2008）は，再帰的近代化という構造変動を補助線と して住民投票を分析している。ここでは，政党やテクノクラートといった「院内」 の政治に対して,「院外」から政治を形作る NGO やNPO などのサブ政治が重要に なった時代の転換点を示すものとして，徳島の住民運動が検討されている．分析に おいては, ダム建設をめぐる社会運動の主張そのものを组上に乗せるのではなく,

「院内」と「院外」の政治過程の考察に徹している．これは住民運動がみずからの 主張の正当性に訴えるのではなく，住民投票によって吉野川のことはみんなで決め るというプロセスの正当性を問うたところを重視するためである．結果として，再 帰的近代への転換を経て現れてきた政治の対立軸に，「院内」の政治が適応してい ないことが明らかにされている.

つまり，「新しい社会運動」的価值観は，制度化したようにみえるものの，議会 政治では必ずしも代表されていない. 政策指向型の運動研究には, こうした龟裂を 見過ごしてしまう陥突があるともいえるだろう。民主主義を主題とする社会運動論 は，議会政治で代表されていない政治を，社会運動を介して政治の場に位置づける 可能性を問題にした。ただし，サブ政治の領域と「新しい社会運動」的価值観が一 致するわけではなく, 争点になる価值観はあらためて検討されねばならない.

今日の状況に鑑みるなら, 環境問題にしても, 反戦・平和問題にしても, 制度化 されたとはいえ，「院外」の価值観が「院内」で影響力をもちえているわけではな い. その意味でいえば, ニュー・ポリティクスのような議論を取り入れた政治学 （賀来・丸山編 2000）は, 現前の事態に対して有効性をもちえないようにみえる. 今日争点になっている社会問題について有効なアプローチは, むしろ「単純な近 代」的な政治学かもしれない.ニュー・ポリティクスは, 「緑」という争点と同時 に「民主主義」のあり方も問うていたのに対して, 後者の側面が必ずしも十分に展 開されなかった結果ともいえるだろう。ただし，民主主義に体現されるような政治 的な側面は, 日本の社会運動研究では別の仕方で探究されており, それについては 次節で検討する.

\section{4 失われた敵対性を求めて}

2000 年代初頭には, 新自由主義が個人の身体に介入する権力を作動させており, それに抗う行為を社会運動として解釈する研究が現れた（酒井 2001; 渋谷 2003）. 
ただし, 渋谷, 酒井の議論は, 社会運動論というよりは権力論といったほうがよい. Hardt and Negri（2001＝2003）にしても，冷戦終結に伴い社会主義という「外部」 が政治的に消滅したグローバル化の時代に出現した新自由主義的資本主義に対する 抵抗のためのマニフェストとしての性格が強い. 新自由主義という新しい権力付置 に対して, 2000 年代半ばまでは, 新しい主体が立ち上がる, つまり社会運動が生 起することを期待する議論が登場した. Hardt and Negri $(2001=2003,2004=$ 2005）は，新自由主義が支配する社会に適合的な身体をもたない個人を運動の担い 手として想定する議論であった。

しかし欧米の反グローバリズム運動ほどには, 新しい権力構造としての新自由主 義という認識は日本において波及力をもたなかった．渋谷（2003）や酒井（2001） は, 新自由主義をフーコー的な生権力として解釈し, システムに適合的な身体が形 成され, 搾取される過程を描いており, むしろ社会運動の不可能性を論じている

Mouffe（2005=2008）によれば，新自由主義は旧来の対立構造をなくすわけで はなく無効化する. Mouffe は再帰的近代化論についても同様の作用を指摘してお $り^{5)}$, 社会運動を説明する権力構造を剔抉する手がかりとなる. 2000 年代の日本に 広がった新自由主義的な, さらには再帰的近代化論的な波を押し戻し, なきものに された敵対線を浮かび上がらせようとする研究を, 以下では検討していく.

1 つめは歴史に根ざす敵対性を明らかにしようとする研究であり, とくに冷戦構 造を背景としてみるのが道場 $(2005)^{6)}$ である. 彼は, 戦後の反戦平和運動の論理 を, それぞれの時代の政治を規定する構造と関連させながら, 2003 年のイラク反 戦運動までの論理と接続すべく読み直す。冷戦期とポスト冷戦期では, 同じ反戦平 和運動であっても運動の論理が異なるという。すなわち, ポスト冷戦期の新自由主 義的思考によって, 反戦平和運動が掲げてきた「非暴力」が「敵対性」の消去と同 一視されるようになった. 抗議型の運動は暴力的で「フッー」でない人が担うもの という思考こそが「敵対性」を消去する, と道場は指摘する. そのようにして運動 のなかに対立が生み出され，問題にすべき敵対線は見失われていく．もっと豊かな 論理を形成してきたはずの戦後の反戦平和運動が,「フッーの人」が忌避する「左 翼的」な論理となる現状に対して,「対話」と経験の分かち合いが必要であるとい j.

2つめが植民地清算を背景にみることで, 過去に引かれた敵対線が現在の社会運 動を規定することを論じる樋口（2014）の『日本型排外主義』である. 後期近代に 特徵的な存在論的不安を抱えた個人が排外主義を担うという説明に対して, 排外主 義は植民地主義の歴史を背景にした地政学的な要因に規定されて形成された個人が 担っているとする.

社会学の社会運動論は, 冷戦終結とグローバル化により「外部」が消滅した状況 を, 暗黙の前提としてきたことを，これらの研究は浮かび上がらせる．東アジアに おける冷戦は終わっておらず, 反安保法制運動などはこうした観点からも分析され るべきだろう。道場と樋口の議論は, 再帰的近代化や生権力としての新自由主義が 
個人に存在論的不安を与えることと, 社会運動の担い手になることは直接的には結 びつかないことを示しており，両者の間に補助線を引く作業といえる.

本来, 新自由主義的生権力はグローバル化を考察せずして検討できない. 再帰的 近代化論も, 抽象化と個人化が進行する後期近代において, エスニシティやナショ ナル・アイデンティティが主体形成の構成要素であると論じている，その意味で, 両者ともグローバル化やナショナリズムといった問題系に開かれていた.

しかし，研究のなかで存在論的不安だけがとりあげられて，いわば構造なき「さ まよう主体」だけが分析の対象となる傾向がみられる. 結果として, 社会運動の分 析がグローバルな構造に開かれておらず，グローバル化のなかでの敵対性が描かれ ていないものが多くなった.

このことは, 現在の日本の社会学において, 外国の社会運動を扱う研究が少ない こととも関連する。事例としての外国研究が寡少なだけでなく, 上述の樋口 （2014）や，以下の山田（2014）や林（2014）を例外として, 国境を越えた政治社 会構造を設定しつつ運動を分析する研究も少ない. 反グローバル運動を扱った野 宮・西城戸編（2016）にしても，実際の議論は内向きである. 日本の政治と社会だ けを材料にしてパズルを組み立てようとしても, そこでは浮上しない敵対性が看過 されてしまう。そうしたなかで，社会運動をグローバルな構造のなかに位置づける とともに, マイノリティからみた敵対性を析出する試みも存在する. グローバル化 と資本の再生産に敵対性をみようとするのが山田（2014）と林（2014）であり，資 本主義システムと社会運動の相互の関係を考察している．山田はアメリカの移民労 働者の運動を「社会運動ユニオニズム」とし， 反システム運動の観点から検討する. 林は資本一国家と都市貧困の関係を, 神奈川のホームレスをめぐる社会運動から考 察する.

もっとも, 山田 (2014), 林 (2014) の議論ではシステムは所与のものであって, 社会運動の担い手はシステムを客体化できるかのように位置づけられている，実際， 当該社会におけるマイノリティたる移民労働者やホームレスは, 前資本主義的な紐 帯を行使し, 資本主義システムに馴致されない身体をもっており, 当該社会で行使 される生権力から逃れているのかもしれない. 資本主義による収奪を社会運動の説 明変数とするため, 運動をみる時間軸が長期にわたることとなり, 運動の変化は議 論の射程におかれることとなる，その結果，移民労働者の運動やホームレス運動は， 構造とは独立したものとして読めてしまう.

理論的には素朴だが，それゆえに理論のもつ陥突に陥らない例外的な研究である 徐（2012）は，アイデンティティ構築が敵対線を引き直す運動でもあることを明ら かにしている，徐の研究は，東大阪市の夜間中学廃止にさいして，在日コリアンの 高齢の女性たちが担い手となり存続を求めた運動を題材にしている. コリアン女性 たちが学校に通うのは，家のなかのジェンダー秩序に変更を迫るものであり，さら には日本社会に在日コリアンの問題を提起するものでもある。これは, 単なるアイ デンティティ構築にとどまらない論点といえるだろう. 
近代から次の時代への政治や価值観の構造転換を分析した研究は, 実は変化の半 分しかとらえていない.つまり, 新自由主義や再帰的近代化, あるいは資本主義シ ステムは，個人をとりまく構造だけではなく，そこに埋め込まれた個人にも変化を もたらした，後期近代に扔いては，産業社会が人生の意味や目的を供給してくれた ような確かな源泉は存在しない，後期近代に打いて，単なる手続き的な民主主義の 問題ではなく，ライフ・ポリティクス（Giddens 1991＝2005）という概念が登場す るゆえんである。

このような存在論的意味の創出も再帰的近代化の重要な論点であるが, 中澤 （2005）や久保田ほか編（2008）の議論では，この点には触れられていない.つま り，市民社会の積極的な担い手として自立しており，アイデンティティにおいても 摇るぎない近代的な主体が想定されている，それに対して，次節でみる論者は，再 州的近代的な身体の行為者に注目した議論を検討する。ただしそこでは，それぞれ が扱う主体が明示的に位置づけられているわけではない. それでも, 存在論的意味 を求めてさまようあり方は再帰的近代の主体と呼ぶにふさわしい.

\section{5 構造なき「さまよう主体」}

社会運動が対立的な形態をとった時代の社会運動概念の解析格子は,「外部」に いる敵手を客観的に対象化した位置に立つことができるという前提にもとづいてい た。しかし，もはや「外部」は消滅した，客体化できる敵手がなくなった結果，権 力を目指さない運動は，ライフスタイル全般にかかわる運動として現れると同時に， 自己の存在そのものにもかかわるようになる.1970年代に抒いてすでに，ライフ スタイルの変革へと内向きに変化を遂げた社会運動があったように，生き方として の社会運動への着目自体は目新しいものではない.しかし，過去の運動の対立的な 側面に焦点を当ててきた日本の社会運動研究に示唆するところは大きい7).

このことを篠原（2004：62）は，「運動はもはやものを勝ち取る手段ではなく, 自己言及的で，それを行うことが自分にとって意味をもつ。この社会における民主 主義は，政治的資源を獲得する競争ではなく，個々人や社会集団が自己を主張する ことのできる状況を，またありのままの自己やかくありたいという自己を受け入れ てもらえる状況を求める」としている.

このような承認の政治は，エスニック・マイノリテイや女性，障害者など，マイ ノリティとしてのアイデンティティを確立している個人にとっては自明の要件であ る.しかし，マジョリティの自己存在証明を社会運動として位置づけるプロセスは 単純ではない. Giddens（1991＝2005）が論じるように，後期近代においては， 個人が自己の物語を自分で紡いでいくことが求められる．個人の人生に意味を与え てくれる源泉はもはや存在せず，今ある自分は，すべて自分の自由な選択の結果と いうことになる。、ジョリティに属する者は，マイノリティほど明確に自己を抑圧 するものを感知できない. 
新自由主義はマジョリティに対しても行使される生権力であることが指摘された が, その後, 社会運動論は, 新自由主義的な権力構造に抵抗する新しい主体を析出 する方向には展開しなかった。むしろ新自由主義的な構造に規定された主体である ことを所与の前提として, 社会運動をアイデンティティ探しの手段として位置づけ る研究が増えていった．社会のなかに居場所を失った個人の自分探し物語である.

そうした研究の 1 つが仁平（2005）による，ボランティア活動という行為をネオ リベラリズムと共振するメカニズムとして描き出すものである．新自由主義に社会 が席巻され，「政府／市場／市民社会」の「不可分地带」として「新たな『公共』」 （仁平 2011：391）として位置づけられた領域で,「ボランティア」として主体化さ れた個人の行為をめぐる言説を分析するものである．ボランティア論が脱政治化さ れて, 結果的に新自由主義に適合的になっていくプロセスを言説分析によって導き 出している.

実際，2008 年末の年越し派遣村は，失業によって社会のどこにも居場所がなく なることを示し，日本社会が新自由主義の論理に覆い尽くされていることを露呈し た.しかし， 2008 年末の反貧困運動が暴露したのは，新自由主義の論理に適合的 でない身体をもつ個人がいかに多いかということではなかったのか. 仁平がボラン ティアを語るときに，その範疇に入るのはおおむねミドルクラスであり，近代的な 自立した個人として新自由主義に適合的な人たちである。つまり，社会には複数の 敵対線が引かれているはずなのに，それがすべて新自由主義に回収されてしまい， もはや市民には敵対する余地が残されていないかのように仁平は結論づけているの ではないか．仁平は，ボランティア論が，「自らの活動がどのような政治的／社会 的帰結と接続しているかを問う基準を忘却し，脱政治的な基準のみで〈贈与のパラ ドクス〉を解決しようとしたときに，国家のネオリベラリズム的動員と適合的にな った」(仁平 2011：422）とする. しかし，「ふたたび『政治』という問題系を取り 戻し，動員に対する批判的な視座を持つことが重要である」という答えを導き出す ことは, 繰り返しボランティア言説に向けられてきた批判として退けている.

社会運動論は, 未だ社会的に可視化されていない敵刘線を明るみに出す役割を担 ってきたはずだが，仁平の議論は，そのような敵対線を消し去る作業に思われる. そこでは敵対線を引くことが「左派的な」所作と片づけられる。 2000 年代に「左 を忌避するポピュリズム」が現れたとする小熊英二を引きながら，ボランティアが 「独善・偽善」と片付けられてしまう文脈に扔いては, 敵対線を引く作業が有効で はないことを示そうとしている8 ${ }^{8}$.

よかれ悪しかれ左右の対立を無化したのが新自由主義である（Mouffe $2005=$ 2008）ならば，敵対線が消し去られるのも新自由主義的な権力の作動の結果ではな いか．そのなかで新自由主義から公共空間を奪い返す試みが，欧米で展開した社会 運動であり，研究の関心もそうした営みに向けられたのではないか．日本は公共空 間を奪い返すどころか，新自由主義に合致しない身体をもつ個人を排除する力のほ うが圧倒的だったことは否定できない，そうした状況への異議申し立てを描き出す 
ことが，第 4 節で検討した，新たな敵対線を引き直すことである．いかなる敵対線 も無効化するシニカルな態度を超えることを仁平は最後に呼びかけてはいるが, 全 体としては敵対線を見失ったミドルクラスの世界を描くにとどまっている．ボラン ティアを「偽善」としシニカルなまなざしを向ける他者に対して, 贈与的なものを 肯定する領域を広げていくべく，「討議に開き，他者への問いを分有させていく」 (仁平 2011：438).このためにも, 敵対線を可視化することが必要なはずだが, 仁 平の論ではそうなっていない. しかし, 同質的な世界で他者に対する想像力を失っ たミドルクラスに対して, 社会運動論が本来的にもちうる意味は, ミドルクラスに 寄り添うことでは得られないように思われる.

そうした観点からすると, 橋口（2011）の『若者の労働運動』は新自由主義的身 体をもたないがゆえに排除され, さまよう主体をとらえている. 社会運動の現場は 闘争の場ではなく，傷付いた個人を癒やし，居場所を提供するものである，ただし そこで癒やされて労働市場に送り返す再生産領域としての役割を果たすわけではな いところに，橋口がフィールドとするフリーターの運動が社会運動たるゆえんがあ る. 新自由主義的に適合的でない身体をそのまま肯定し,「働かない」という選択 肢を提示することで, 新自由主義によって消し去られた敵対線を浮かび上がらせよ うとしている．新自由主義によって自己の存在意義を否定されてしまう状況は, 出 口をみつけるのが難しいという意味で深刻である. 主体の確立どころか, 自分はこ の社会に存在していてよいのか, という問いが運動の担い手から発せられるときに, 社会運動がマイノリティの「居場所作り」としての機能を果たしているのが現在の 日本の社会運動の状況ということであろう.

それとは対照的に, 小熊の『1968』は分析する側にいる社会学者が, 新自由主義 的な権力構造や再帰的近代を対象化できずに取り込まれてしまった議論として読む ことができる. 1968 年の学生運動は, 一方では学生にとっての民主化運動だった. 他方で,「戦争・貧困・飢餓といった『近代的不幸』とは次元が異なる, いわば 『現代的不幸』—アイデンティティの不安・未来への閉塞感・生の実感の欠落・リ アリティの希薄さ」への抵抗として学生運動は描かれる. しかし, 心理的葛藤を自 ら言語化できず, それをマルクス主義の流用で補ったのが「1968 年」だった，と いうのが小熊の説明になる ${ }^{9)}$.「現在の若者の問題とされている不登校, 自傷行為, 摂食障害, 空虚感, 閉塞感といった『現代的』な『生きづらさ』のいわば端緒が出 現し, 若者たちがその匂いをかぎとり反応した現象であった」(小熊 2009 上: 14). すなわち, 高度成長期で従来の制度や思想的枠組みが有効性を失い, アイデンティ ティ・クライシスに陥った若者の「自分探し」として 1968 年は解釈される（小熊 2009 下: 610).

そうした若者の「自分探し」に対する欲求を理解できなかったセクトが, 浅間山 荘事件に至る内ゲバを繰り広げて自滅していった。 それに対し，小熊によればセク トの用語では自己表現できないと感じていた「どこへも入るところがない」若者の 受け皿となったとされるべ平連は, 「『1968』年と日本の社会運動を考える上で, 現 
在でも学びとるべき多くの教訓と知恵が含まれていた」(小熊 2009 下: 499).

べ平連が「いわば不定形な運動」で，「各人がどのような解釈を加えることも可 能だったがゆえに，言葉にならない『現代的不幸』から逃れたい若者たちの受け血 になっていた」(小熊 2009 下：383)。このような解釈は, 人が存在論的不安を感じ ていて, そこに適切な受け典が用意されれば, 人々は運動に参加するという前提に もとづく，もちろん，七クトのように解釈を暴力的に押しつけない，「普通の市民」 が入りやすい運動が枠組みを提供することが前提だが, そうだとしても 19 世紀の 群衆心理学を彷彿させる社会運動理解である ${ }^{10)}$.

2000 年代の日本社会が新自由主義に押し流されて敵対線が消し去られて, 再帰 的近代を生きる個人が社会運動に「生き甲斐」や「居場所」を求めるようになった というリアリティの認識が妥当だとしょう. だとしても, 小熊もまた近年の社会運 動をもっぱら「自分探し」の観点から説明しょうとする研究の潮流に舵をとられて, 過去の社会運動をみずからも新自由主義に貫かれたまなざしで読んでしまったので はないか. 東大全共闘の「自己否定」の論理を，アイデンティティ・クライシスに よる「自分探し」に読み替えてしまうことは, 社会運動やNPOに「居場所」の機 能を求める現在の潮流をそのまま反映しているように思われる.

もちろん, 再帰的近代は 1970 年代から顕在化していると Beck et al. (1994= 1997）は論じており，1968 年の若者が存在論的意味を求めてさまよっていたとし て何ら不思議はない.しかし 1968 年の社会運動が「現代的不幸」や「自分探し」 要求にもとづくものならば，なぜ特定のイシューを揭げる社会運動だけが自分探し の土壤になって, 他のイシューではありえないのかが説明できない. 個人に存在論 的意味を与えてくれる場として社会運動を解釈する立場をとると, 社会運動論は限 りなくサブカルチャー研究に近づくだろう，社会運動のイデオロギーまでもアイデ ンティティ構築に還元してしまうことは, 運動が提示する社会構造に根ざした争点 をなおざりにしてしまうのではないだろうか. そのような構造がもはや存在しない かのように社会運動を组上に載せることは, 可視化されていない構造によって, 相 変わらず抑圧されている主体の存在をなきものにする.

セクトのような組織に動員されたのではなく，個人が自発的に存在論的理由から 社会運動に参加するようになったことを,「どこへも入るところがない」人すべて に開かれている運動として額面通り評価してしまうと, 個々の行為者がその存在ゆ えにもつ政治性が消し去られてしまう。その結果, 政治性ゆえに排除される行為者 を視野の外へと押しやることになる．誰もが対等なのだ，ということの政治性を自 覚しない社会学者の政治性を, 社会運動研究はどのように克服できるのか. それが 次節のポスト近代主義的な主体の問題である.

\section{6 ポスト近代主義的な主体を求めて}

そもそも近代というプロジェクトは, 自立した自由な個人を想定しており，これ 
がまさしく社会運動の主体的な行為者として想定されてきた。しかし，今日そうし た近代的「主体」概念そのものもにも，疑いのまなざしが当然向けられるようにな った。

近代社会は歴史をつうじて, 個人と個人の関倸を, 契約的なもの, 功利主義的な ものに置き換えていった，そうであるならば，個人主義化のなかで変容していった 人間関係を問い直す要素が社会運動のなかに必然的に現れてくるはずである.

大畑（2004）は Giddens（1991=2005）が論じる「ライフ・ポリティクス」が今 日主流になっているとし，「『自由な』選択を行えるようになった個人が，どのよう な基準にもとづいて, さまざまな選択肢のなかからどのような選択を行うかが問題 になる」とする．再帰的近代化という社会変動がいかなる主体を出現させたかとい う問題が提示されている. 大畑の議論を突き進めれば, 現状では研究者の側のまな ざしが旧来的な主体しかとらえることができていないことになる．近代主義を批判 するためには, ポスト近代主義的な主体の出現をとらえる研究者のまなざしも必要 である.

近代的「主体」概念への疑いのまなざしは，近代的な主体を担い手として想定し た社会運動を見直すことにもつながる. 成（2003）は, 初期水俣病運動が, 公害問 題や環境問題として, つまり普遍的なテーマとして闘われたのではなく, 水俣病患 者の「直接性／個別性」の表出として闘われたことに注目している. 成は, 水俣病 患者の運動が，代理＝表象を排除し，「直接性／個別性」に執着してきた事実に， 近代市民社会においては, あらゆる存在が普遍的なシステムに媒介され, 社会関係 が非人格化するような精神構造, 社会構造を突き抜ける突破口を見出す.

近代市民社会的な社会運動は, ヴェーバー的な目的合理性の追求に逢着し, その 意味で,「誰」が担い手となるかは問わない，水俣病患者の当事者たちは，2ずか らが担い手とならなくても, 支援者たちが目標を達成してくれるのを待っていても よかったはずである，そうではなく，「誰が」ということにこだわり，後述するよ うに「当事者性」を重視する社会運動論が展開する. 当事者性を追求する運動は, マイノリティが担い手である場合には, Melucci $(1989=1997)$ が議論するような 支配的コードに対する挑戦として位置づけられるだろう。しかし，支配／被支配と いう単純な権力関係に還元されてしまうと，マジョリティが加害性を認めてマイノ リティが被った被害を補償するという図式しか導き出されない. 水俣病は産業化と いう近代化の中核が生み出したものである. 近代化が個人を抽象化していくなかで, 運動によって個別性／直接性を取り戻す, そのような近代に対する抵抗として成 （2003）は社会運動を再解釈している.

成（2001）は, 水俣病運動や有機農業を, 「モラル・プロテスト」の概念を用い て,「水俣病を生み出す現代の精神構造や社会構造」から転回する方向性を示す運 動としてとらえる. 戦後の社会運動は近代の矛盾を追求し, 生活環境を壊す開発主 義を担うテクノクラートに対抗するものだった．しかし，「モラル・プロテスト」 は対立的な形態をとらない. 被害/加害=個人/テクノクラートや企業といった旧 
来の対立構造に還元するのではなく, 個人もそこに埋め込まれている構造を再発見 する. 社会運動の担い手もマクロ・ミクロな権力関倸を構成して㧍り, そこから逃 れることができない以上, 運動に参加するという行為が, 権力関係の布置のなかで もつ意味の検討を避けられないことを前提としている.

政治的機会構造論に対する, 文化的アプローチによる批判などは, ポスト近代社 会的な行為者の「抵抗」を把握することができない理論枠組みへの批判といえる. 新自由主義的に席巻された今日の状況への理論的抵抗は, 過去の敵対線を呼び戻す ことだけではない。「自由で自立した主体たれ」という近代のプロジェクトに抵抗 する主体を立ち上げる必要性を, 成の議論は示唆している.

それを敷衍していえば，自立した個人であることを強制する社会システムに対抗 する社会運動を析出する方法の 1 つは，近代的意味で「ダメな主体」を「発見」す ることにあるのではないか. 中西・上野（2003）の「当事者主権」は，そうした観 点から読むことができる。「能率，効率がもっとも尊ばれる社会のなかにあって， もっとも適応しなかった人たちの集団，庇護と管理の下に置かれたマイノリティと 言われる人たち」(中西・上野 2003) を担い手とする運動が開示する争点の検討で ある. 自覚的かどうかは別として，近代的主体概念のパラダイムを書き換えようと する試みと理解することもできよう.

それとも関連して, 井上（2002）は「スティグマを貼られた人々の主体性」を 「ルサンチマン」としてとらえる。「自分はこれでいいんだ，ありのまま存在するこ とを認めて欲しい」というマイノリティの主張は, 開き直りとコインの裏表の関係 を成すという，井上は，「近代」が産み出した社会運動の主体が「近代的」個人を 自明としていることの抑圧的側面を描き出しているといえる.

このように近代主義へのアンチである社会運動を分析するには，近代的価值観に 合致しない主体の析出が不可欠であろう。ただしそこでマイノリティが近代的主体 として立ち上がって社会運動の担い手となるプロセスを描くのでは, 支配的文化へ の同化の物語になる危険性を常にはらむ.

\section{7 結びにかえて}

新自由主義や再帰的近代化論といった新しい構造が発見されることで, 旧い敵対 線は葬り去られた。しかし敵対性を旧いものとして消し去った社会運動論は, ある 社会運動が構造に対してどのような変化を及ぼし, その変化が個々の社会のメンバ 一にどのような意味をもつかの分析を放棄してしまった.

個人に存在の意味を供給するだけの役割から社会運動を解放することが, 社会運 動論に求められているのではないだろうか.つまり,「さまよう主体」が実は行使 している政治性を明らかにして, 敵対線を引き直すことが必要とされている. マジ ヨリティが「さまよう主体」たる今日，敵対線を理解する枠組みを提供しているの は, 一方では「単純な近代」的なオーソドックスな政治学であった，反安保法制運 
動での政治学者の発言が示すように，議会内での政党政治との間に敵対線を引くよ うな説明は今でも有効性をもつ.では社会運動論は何をなすべきか. 政治ではなく 市民社会のなかに政治性を発見し，そこに敵対線を引き直していくことになるので はないだろうか.

\section{[注]}

1）本稿で扱う「応用」社会運動論の他に, 行動科学を背景にした社会運動論の「純粋科学」化 —これ自体は 1990 年代のアメリカで流行したものだが——もられる. 社会運動を規定す る制度的条件を数值化, モデル化して分析する数理社会学は, 社会運動論のもう一方の極を形 成している.

2）両者の間には一定の断絶があるが, 政策志向の社会運動論が後者の論点を取り入れる余地も 残されている. 抗議型ではない運動だとしても, 社会システムや社会構造に対して社会運動が 固有に果たす役割や社会的機能があるはずである（安立 2008）。それを社会変動との関係で理 解し直すことが，政策指向の社会運動論が果たす理論的な役割なのではないか.

3）同じく巻町を対象にして, 中澤が論じていない点を中心的に論じているのが伊藤ほか （2005）である. それによると保守対革新という従来の政治構造から疎外された人々が, みず からの判断と意思表示の舞台として用意したのが住民投票であったとされる．中澤が政策の中 味よりも手続き論が運動拡大に寄与したと考えるのに対し, 伊藤らは, 新しい社会運動論的価 值観が受け入れられたことから説明する. 一方で 1990 年代半ばを境として, ボランティア活 動や政治的意思表明の新しい形態やスタイルが登場してきたことも指摘される. それにもとづ き, 熟虑民主主義の概念を援用して, 従来の政治制度のみによらず, 複雑化する社会で多様な 価値観に基づく政治的争点を熟慮する場を市民自身が組織する試みであることを示唆している (伊藤ほか 2005: 277). しかし, ここで伊藤らが析出する価值観と多様性は, ジェンダー, 世 代，階層といった 1970 年代から変わることのない要素にとどまっている，70 年代とは異なる 要素と運動の新しさの結びつきを, 運動の組織や戦略から検討すべき時期ではないだろうか.

4）そのため, 新自由主義的な権力構造に抗う主体が形成されたのか否かは検証しょうがない. 新自由主義に反対する抗議行動の典型例である反 G8 のデモ参加者数をみると, 警察庁の資料 では 2007 年のハイリゲンダム・サミットの約 8 万人に対して, 2008 年の洞爺湖サミットは約 5,000 人であった.

5）存在において自由であり自己決定する近代的な主体を立ち上げる点で, 新自由主義的権力と 再帰的近代化の個人に対する作用は似ている. エスニシティやナショナリティ, ジェンダーや セクシュアリティといった権力関倸を構成し, 社会運動の争点となる要素が, 再帰的近代化論 においては, 個人の選択的なアイデンティティ構築の素材として平面的に等価なものとして並 列されてしまう。.

6）道場自身の著書だけでなく, 創土社から 2005 年に刊行された「復刻・シリーズ 1960/70 年 代の住民運動」の編纂も, 同様の試みとして位置づけられるだろう。

7） 1980 年代以降の日本の社会運動論の特徵は, アメリカの影響の強さとマルクス主義の影響の 小ささだろう。それゆえ, 冷戦やそれ以降の世界政治によって社会運動が規定されているとい う認識は, 社会運動論でそれほど重要なポイントとして議論されてこなかった.

8）もっとも仁平 (2005) は, ボランティア活動という市民の主体的な参加が, システムに適合 的で統治可能な主体創出に利用されるという中野 (2001) が指摘する問題に対して, 理論上そ のように主体を十把一絡げに論じることはできても, 実証にもとづいて議論するならば, 「主 
体」はどのように主体化されるかによって，他者に対して排除的にもなりうるし，共感的にも なりうる可能性を示している。「民主主義」が手続きの問題であるように,「主体」もあらかじ め決定されているわけではなく、「主体的な行為」は現実の社会関係のなかでしか形成されな いことを指摘している.

9）小熊は『1968』の中心概念である「近代的不幸」と「現代的不幸」を導き出す理論的根拠は 提示して扔らず，当時の社会学者や政治学者の分析に依拠している．小熊の論じる「近代的不 幸」は Giddens $(1991=2005)$ の「解放政治」に対応し，「現代的不幸」は「生活政治」に対応 している．ただし小熊が「現代的不幸」が「当時他の先進諸国でもおきた学生叛乱も共通して いる」とする根拠としてあげるのはデヴィッド・リースマンである. 歴史的資料として用いて いるにしても, 理論枠組みを提示する根拠にもしているわけで, その観点からは一世代古い感 は否めない（小熊 2009 上：159).

10）小熊は, 資料に忠実に当時の若者の動機を再現するために, 当時の資料を使いインタビュー は行わないとしている．「人間の記憶は変形するものだからだ」(小熊 2009 上：21）という.

しかし回想記を利用する場合を「やむをえず」と断ってはいるが（小熊 2009 上：18)，アイデ ンティティ・クライシスだったという結論の裏付けとなる活動家の少なから好発言は 1990 年 代以降の回顧録に依拠している.こうした方法論的な難点も，現在のパラダイムを過去に投影 する一因になっているのかもしれない.

\section{[文献]}

安立清史, 2008, 『福祉 NPO の社会学』東京大学出版会.

Beck, Ulrich, Anthony Giddens and Scott Lash, 1994, Reflexive Modernization: Politics, Tradition and Aesthetics in the Modern Social Order, Stanford, Calif.: Stanford University Press. (=1997, 松尾精文 - 小幡正敏 - 叶堂隆三訳『再帰的近代化一一近現代における政治, 伝統, 美的原理』 而立書房. )

Giddens, Anthony, 1991, Modernity and Self-Identity: Self and Society in the Late Modern Age, Stanford, Calif.: Stanford University Press. (=2005, 秋吉美都・安藤太郎・筒井淳也訳『モダ ニティとセルフアイデンティティ—後期近代における自己と社会』ハーベスト社. )

Hardt, Michael and Antonio Negri, 2001, Empire, Cambridge, Mass.: Harvard University Press. (= 2003，水島一憲ほか訳『〈帝国〉——゙ローバル化の世界秩序とマルチチュードの可能性』以文 社. )

,2004, Multitude: War and Democracy in the Age of Empire, New York: Penguin. ( = 2005,

幾島幸子訳『マルチチュード—〈帝国〉時代の戦争と民主主義』上・下, 日本放送出版協会. 長谷川公一, 2003, 『環境運動と新しい公共圈——環境社会学のパースペクティブ』有斐閣.

一編, 2001, 『環境運動と政策のダイナミズム』有斐閣.

橋口昌治, 2011, 『若者の労働運動——働かせろ」と「働かないぞ」の社会学』生活書院. 林真人, 2014,『ホームレスと都市空間——収奪と異化, 社会運動, 資本一国家』明石書店. 樋口直人, 2014, 『日本型排外主義——在特会 - 外国人参政権・東アジア地政学』名古屋大学出版 会.

本郷正武, 2007, 『HIV / AIDS をめぐる集合行為の社会学』ミネルヴァ書房.

井上芳保, 2002,「対抗的社会運動とルサンチマン処理文化」野宮大志郎編『社会運動と文化』ミ ネルヴァ書房, 103-34.

伊藤守ほか, 2005, 『デモクラシー・リフレクション——卷町住民投票の社会学』リベルタ出版. 賀来健輔・丸山仁編, 2000, 『ニュー・ポリティクスの政治学』ミネルヴァ書房. 
久保田滋ほか編, 2008, 『再帰的近代の政治社会学——吉野川可動堰問題と民主主義の実験』ミネ ルヴァ書房.

Melucci, Alberto (John Kean and Paul Miler eds.), 1989, Nomads of the Present: Social Movements and Individual Needs in Contemporary Society, Philadelphia: Temple University Press. (= 1997, 山之内靖・貴堂嘉之・宮㠃かすみ訳『現在に生きる遊牧民一新しい公共空間の創出に向け て』岩波書店. )

道場親信, 2005, 『占領と平和——戦後」という経験』青土社.

Mouffe, Chantal, 2005, On the Political (Thinking in Action), London/New York: Routledge. (= 2008, 酒井隆史監訳, 篠原雅武訳『ラディカル・デモクラシー 1 政治的なものについて—闘 技的民主主義と多元主義的グローバル秩序の構築』明石書店. )

中西正司・上野千鶴子, 2003, 『当事者主権』岩波書店.

中野敏男, 2001, 『大塚久雄と丸山眞男一一動員, 主体, 戦争責任』青土社.

中澤秀雄，2005，『住民投票運動とローカルレジーム——新潟県巻町と根源的民主主義の細道 19942004』ハーベスト社.

仁平典宏, 2005, 「ボランティア活動とネオリベラリズムの共振問題を再考する」『社会学評論』56 (2) : 485-99.

—, 2011, 『「ボランティア」の誕生と終焉—〈贈与のパラドックス〉の知識社会学』名古 屋大学出版会.

西城戸誠, 2008, 『抗いの条件一一社会運動の文化的アプローチ』人文書院.

野宮大志郎・西城戸誠編, 2016, 『サミット・プロテスト—ーグローバル化時代の社会運動』新泉 社.

帯谷博明, 2004, 『ダム建設をめぐる環境運動と地域再生——対立と協働のダイナミズム』昭和堂. 小熊英二, 2009, 『1968』上·下, 新曜社.

大畑裕嗣, 2004,「モダニティの変容と社会運動」曽良中清司ほか編『社会運動という公共空間 ——理論と方法のフロンティア』成文堂, 156-89.

酒井隆史, 2001, 『自由論——現在性の系譜学』青土社.

SEALDs（自由と民主主義のための学生緊急行動)，2015，『SEALDs一民主主義ってこれだ!』 大月書店.

渋谷望, 2003, 『魂の労働——ネオリベラリズムの権力論』青土社.

篠原一, 2004『市民の政治学——討議デモクラシーとは何か』岩波書店.

徐阿貴, 2012, 『在日朝鮮人女性による「下位の対抗的な公共圈」の形成一大阪の夜間中学を核 とした運動』御茶の水書房.

成元哲, 2001,「モラル・プロテストとしての環境運動——ダイオキシン問題に係わるある農家の 自己アイデンティティ」長谷川公一編『環境運動と政策のダイナミズム』有斐閣, 121-46.

—, 2003, 「初期水俣病運動における『直接性／個別性』の思想」片桐新自・丹辺宣彦編『現 代社会学における歴史と批判・下 近代資本制と主体性』東信堂, 83-104.

曽良中清司ほか編, 2004, 『社会運動という公共空間——理論と方法のフロンティア』成文堂. 高橋源一郎・SEALDs, 2015, 『民主主義ってなんだ?』河出書房新社.

山田信行, 2014, 『社会運動ユニオニズム—グローバル化と労働運動の再生』ミネルヴァ書房. 